UDC 541.48-143:542.61

\title{
EXTRACTION ENNOBLEMENT OF DIESEL DISTILLATE AND ITS CLOSE-CUT FRACTIONS
}

\author{
M.J.Ibrahimova, S.A.Seyidova, S.G.Aliyeva, H.D.Huseynov, V.A.Naghiyev, \\ A.B.Khalilov, S.F.Ahmadbayova, S.Sh.Huseynova
}

Y.H.Mammadaliyev Institute of Petrochemical Processes, NAS of Azerbaijan

minaver-ibrahimova@rambler.ru

Received 13.06.2018

\begin{abstract}
The results of the studies, carried out on the initial diesel distillates, and also raffinates and extracts, obtained by their extractive purification in the presence of ionic liquid on the basis of N-methylpyrrolidone and acetic acid as a selective solvent are presented. Hydrocarbon compositions of the raffinate and extract, obtained by selective purification of diesel distillate and its close-cut fractions has been determined by IR spectral analysis. Advantages and prospects of used ionic liquid have been presented in comparison with $\mathrm{N}$-methylpyrrolidone in the processes of selective purification of diesel distillate.
\end{abstract}

Keywords: ionic liquid, extraction, extractant, distillate, diesel fuel, selective solvent, raffinate, extract.

\section{Introduction}

Currently, extraction method for selective purification of petroleum fractions is being actively developed. Selective purification provides removal of the components from the petroleum fractions, having negative effects on exploitation properties of commercial petrochemicals, obtained on their basis. Unintended components in the target product include polycyclic aromatic and naphthene-aromatic hydrocarbons with short lateral chains, sulphidic and nitrogen compounds and also resinous substances. The depth and selectivity of the extraction purification of the raw material is determined by dissolving power, as well as the selectivity of the solvent used - the extractant selected in accordance with the requirements for the quality of the product obtained, i.e., the group hydrocarbon composition of the raw material to be purified.

Among all types of commercial petroleum products, diesel fuel (trucks, railways, agricultural machinery etc.) occupies a special place, which is connected with an increase in the volume of car parks using diesel fuel. In particular, the volume of diesel fuel production in Russia in the period until 2030 should be 106-111 million tons per year [1].

Increasing demand for diesel fuel causes toughening the requirements for its quality, which proves the need to develop the processes that permit to obtain environmentally friendly diesel fuels meeting modern and prospective requirements of European standards. In this aspect, a special attention is paid to the content of sulphur-containing compounds and polycyclic aromatic hydrocarbons in the fuel composition, as well as to the cetane number of fuel.

Accordingly, for improving fuels quality, in particular, diesel one, in recent years, along with hydrogenation methods of purification, extraction methods have been successfully applied using various compositions as a selective solvent [2-5]. Since, hydrofining method makes possible significant reduction in diesel fuel sulphur content, but in this case, aromatic hydrocarbons aren't reduced to the desired level.

The extractive method of purification differs both by the simplicity of technological implementation and possibility of simultaneous removal of the above-mentioned undesirable components from the composition of studied raw materials; at the same time, cetane number of diesel fuel produced is also increased. In the known methods for the extraction of petroleum fractions, organic solvents such as phenol, furfural, N-methylpyrrolidone, morpholine, sulfolane, aniline, diethyl ketone are widely used, they are characterized by high selectivity, but these extracts are toxic ones.

In this regard, the development of conditions for extractive purification of diesel distil- 
late using non-toxic solvents, ionic liquids (IL) is a pressing task of oil refining.

Application of ionic-liquid compositions in the processes of extractive purification of oil fractions is presented in [6-9]. The researches results of desulphurization of gasoline (desulphurization degree $-30 \%$ ) and diesel fuel by the method of extractive purification in the presence of IL as a selective solvent are presented in [10].

The usefulness of IL in the processes of selective purification of diesel distillate by extraction method is revealed by the cycle of systematic studies carried out in academician Y.Mammadaliyev Institute of Petrochemical Processes of Azerbaijan National Academy of Sciences [11, 12]. In particular, it was shown that aromatic hydrocarbons in the distillate are decreased from 16.5 to 10.5 mas\%, and sulphur - from 0.089 to $0.034 \mathrm{mas} \%$ by the IL on the basis of formic acid and aniline or morpholine as a result of selective purification of diesel fuel produced in Heydar Aliyev Baku Oil Refinery. Simultaneously, decrease in the content of resinous compounds was observed, which is confirmed both by the clarity of the purified diesel fraction and decrease in its specific gravity and refractive index as compared with the initial one.

High efficiency of using IL on the basis of $\mathrm{N}$-methylpyrrolidone and formic or acetic acids as extracts is revealed in the subsequent studies [13].

\section{Experimental part}

This article deals with the results of the studies carried out on the raffinate and extract phases compositions obtained by selective purification of diesel distillate (DD) produced in Heydar Aliyev Baku Oil Refinery, as well as the fractions isolated by distillation of this distillate at Engler plant using ionic liquids on the basis of $\mathrm{N}$-methylpyrrolidone and acetic acid as selective solvent.

Determination of the parameters of the initial DD and extracted fractions (Table 1) reveals that $\mathrm{DD}$ at a boiling point below $250^{\circ} \mathrm{C}$ is characterized by a low content of aromatic and sulphur-containing compounds relatively than the original distillate and fractions with boiling points of $250-300^{\circ} \mathrm{C}$ and $300-345^{\circ} \mathrm{C}$.
Table 1. Properties of diesel distillate and extracted fractions

\begin{tabular}{|c|c|c|c|c|}
\hline \multirow{2}{*}{ Properties } & \multirow{2}{*}{$\begin{array}{l}\text { Diesel } \\
\text { distil- } \\
\text { late }\end{array}$} & \multicolumn{3}{|c|}{ Extracted fractions of DD } \\
\hline & & I frac. & II frac. & III frac. \\
\hline $\begin{array}{l}\text { Fractional composi- } \\
\text { tion, }{ }^{0} \mathrm{C}\end{array}$ & & & & \\
\hline b.p. & 191 & 191 & 250 & 300 \\
\hline e.b. & 350 & 250 & 300 & 345 \\
\hline Yield, mas\% & - & 21 & 46 & 29 \\
\hline $\begin{array}{l}\text { Kinematic viscosity, } \\
\mathrm{mm}^{2} / \mathrm{s} \text { at } 20^{\circ} \mathrm{C}\end{array}$ & 6.47 & - & - & - \\
\hline Refractive index, $n_{D}^{20}$ & 1.4629 & 1.4464 & 1.4619 & 1.4719 \\
\hline $\begin{array}{l}\text { Density at } 20^{0} \mathrm{C} \\
\mathrm{kg} / \mathrm{m}^{3}\end{array}$ & 852.3 & 850.2 & 849.6 & 878.7 \\
\hline $\begin{array}{l}\text { Composition: } \\
\text { aromatic hydro- } \\
\text { carbons, mas } \% \\
\text { sulphur, ppm }\end{array}$ & $\begin{array}{l}12 \\
983\end{array}$ & $\begin{array}{c}8 \\
596\end{array}$ & $\begin{array}{l}10 \\
789\end{array}$ & $\begin{array}{c}12 \\
1055\end{array}$ \\
\hline
\end{tabular}

Extractive purification of initial DD and extracted fractions was carried out at the weight ratios of: raw material:IL equal to $1: 2$, extraction temperature $-22-25^{\circ} \mathrm{C}$, and duration of the components contact - for $1 \mathrm{~h}$. Purification selectivity and qualitative parameters of the raffinates and extracts obtained by selective purification of DD and corresponding fractions are set into Table 2 .

Table 2. Properties of diesel fuel and extracted fractions after extractive purification

\begin{tabular}{|c|c|c|c|c|c|c|c|}
\hline \multirow[b]{2}{*}{ 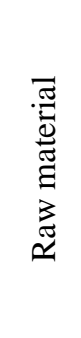 } & \multicolumn{2}{|c|}{ Yield, mas\% } & \multicolumn{5}{|c|}{ Raffinate indices } \\
\hline & 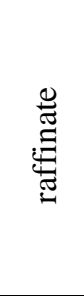 & 苛 & 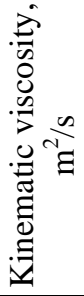 & 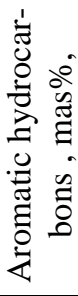 & 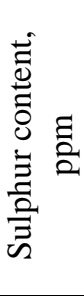 & 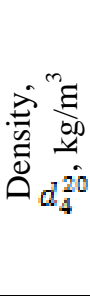 & 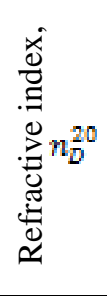 \\
\hline DD & 78.83 & 18.1 & 6.62 & 8.0 & 577 & 834.4 & 1.4636 \\
\hline I fr. & 80.0 & 19.5 & 3.37 & 5.0 & 353 & 823.7 & 1.4524 \\
\hline II fr. & 81.33 & 18.2 & 5.63 & 6.0 & 565 & 835.2 & 1.4590 \\
\hline III fr. & 91.2 & 8.1 & 5.57 & 8.0 & 844 & 847.7 & 1.4702 \\
\hline
\end{tabular}

As is evident from the results, the yield of DD purified under these conditions amounts to $78.83 \mathrm{mas} \%$. The residual aromatic content in the resulting raffinate is 8.0 mas\%, sulphur $577 \mathrm{ppm}$. The yield of raffinates obtained by selective purification of diesel distillate above fractions by the above-mentioned ionic liquid varies within the range of 80.0-91.2 mas\%. Dearomatization degree of the I fraction of DD 
is 37.5 mas\% with a residual aromatic content in the raffinate of 5.0 mas\%. Dearomatization degree of the II fraction is higher - 40 mas\% than initial DD and the I fraction. The residual aromatic content amounts to $6.0 \mathrm{mas} \%$.

The highest desulphurization degree is observed in the extractive purification of initial DD and the close-cut fraction obtained on its basis with boiling point of $191-250^{\circ} \mathrm{C}$. In particular, the residual sulphur content in the raffinate on the basis of the long distillate of DD with boiling point of $191-345^{\circ} \mathrm{C}$ amounts to 577 ppm with desulphurization degree of 41.3 mas $\%$, and in the raffinate obtained by the extractive purification of the fraction with boiling point of $191-250^{\circ} \mathrm{C}-353 \mathrm{ppm}$ with desulphurization degree of 40.77 mas\%. The lowest desulphurization degree is observed for the fraction of DD with boiling point of $300-345^{\circ} \mathrm{C}$ and amounts to 20 mas\%.

The raffinate, obtained by the extractive purification of the I fr. of DD has the highest value of cetane number (c.n.=54).

The results are confirmed by comparative IR spectral analysis of DD identified as a raw material, extracted from diesel fractions, as well as the raffinates and extracts obtained as a result of selective purification in the presence of ionic-liquids. IR spectroscopic analysis of the samples was carried out by infrared Fourier spectrometer ALPHA of BRUKER (Germany) in the wave-frequency range of $600-4000 \mathrm{~cm}^{-1}$.

As is evident from Figure 1, IR spectra of DD and extracted fractions are characterized by the presence of similar absorption bands:

- bending $\left(723,1376,1458 \mathrm{~cm}^{-1}\right)$ and valence $\left(2853,2921,2953 \mathrm{~cm}^{-1}\right)$ vibrations of $\mathrm{C}-\mathrm{H}$-bond groups of $\mathrm{CH}_{3}$ and $\mathrm{CH}_{2}$;

- bending $(699,722,742,781,807$ or 710 , $1604 \mathrm{~cm}^{-1}$ ) vibration of C-H-bond of substituted benzene ring.

IR spectra of the relevant raffinates (Figure 2) obtained by ionic-liquid extraction are characterized by the presence of:

- bending $\left(722,1376,1457 \mathrm{~cm}^{-1}\right)$ and valence (2853, 2921, $\left.2953 \mathrm{~cm}^{-1}\right)$ vibrations of the $\mathrm{C}-\mathrm{H}$-bond of the $\mathrm{CH}_{3}$ and $\mathrm{CH}_{2}$ groups;

- bending 722, 813, 807, $1603 \mathrm{~cm}^{-1}$ ) vibrations of the $\mathrm{C}-\mathrm{H}$-bond of the substituted benzene ring; however, in the IR spectra of raffinates, there is a significant decrease in the intensities of the absorption bands of the $\mathrm{C}-\mathrm{H}$-bond of the substituted benzene ring (807 and $1604 \mathrm{~cm}^{-1}$ ) in comparison with the IR spectra of the corresponding initial distillates.

IR spectra of the extracts (Figure 3) obtained by ionic-liquid extraction are characterized by the presence of:

- bending $\left(1376,1455 \mathrm{~cm}^{-1}\right)$ and valence $\left(2854,2921,2952 \mathrm{~cm}^{-1}\right)$ vibrations of $\mathrm{C}_{-}$ H-bonds of $\mathrm{CH}_{3}$ and $\mathrm{CH}_{2}$ groups;

- bending (699, 744, 782, 810, 872, 1602 $\mathrm{cm}^{-1}$ ) vibrations of $\mathrm{C}-\mathrm{H}$-bond of the substituted benzene ring;

- as well as bending $\left(956,1032 \mathrm{~cm}^{-1}\right)$ vibrations of $\mathrm{C}-\mathrm{H}$-bond belonging to $\mathrm{CH}_{2}$ group of naphthenes.

Comparison of IR spectra of diesel distillates, raffinates and extracts proves the change in the intensities of absorption bands of $\mathrm{C}-\mathrm{H}$-bond of substituted benzene ring in the region of 807 and $1604 \mathrm{~cm}^{-1}$.

In particular, IR spectra of raffinates reveal the decrease in the intensities of absorption bands related to the benzene ring, while in IR spectra of the extracts, on the contrary, the intensities of these absorption bands increase.

Calculated optical densities of absorption bands 1376, 1357, 1455, 1604, 1033 and 959, $970 \mathrm{~cm}^{-1}$, respectively, characterizing bending vibrations of $\mathrm{C}-\mathrm{H}$-bond of naphthenes methyl group and the $\mathrm{CH}$ bond of substituted benzene ring, as well as bending vibrations of methylene and methyl fragments $\mathrm{CH}$ bonds are set into Table 3.

As is seen, during the extractive purification, decrease in the concentration of aromatic hydrocarbons in the raffinate causes decrease in the index of absorption bands optical densities, which characterize the benzene ring from 0.006 to 0.001-0.002, depending on the raw material. Simultaneously, the optical densities of these absorption bands are significantly greater than 0.013-0.022 in the corresponding extracts.

The presence of absorption bands related to $\mathrm{CH}$ bond in $\mathrm{CH}_{2}$ groups of naphthenes is observed in IR spectra of the extract separated 
from DD and the above-mentioned DD fractions, and it reveals the removal of naphthene- aromatic hydrocarbons during extraction purification by ionic-liquid composition.

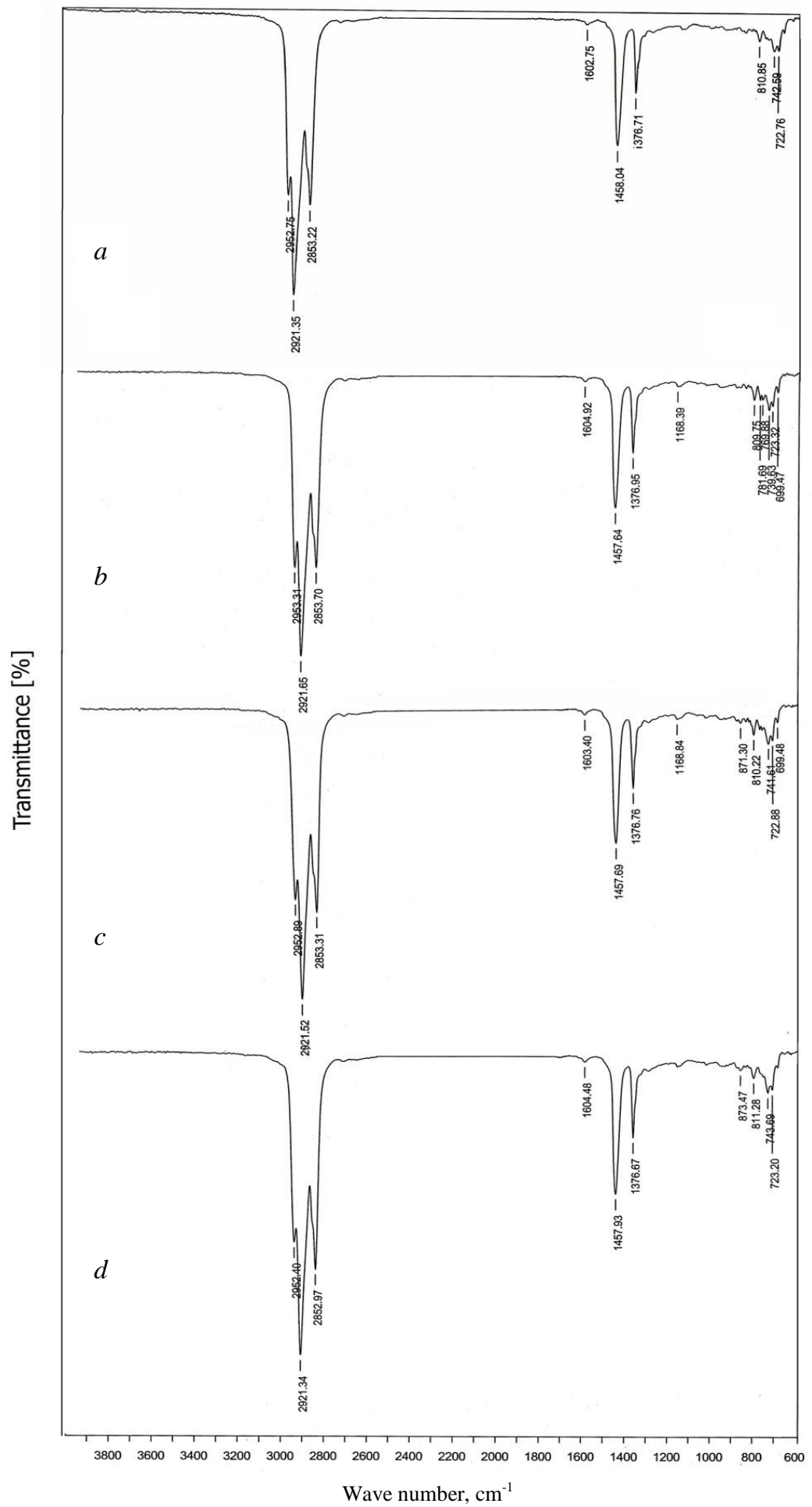

Fig. 1. IR spectra of diesel distillates: initial DD $(a)$, DD of the I fr. (b), DD of the II fr. (c), DD of the III fr. $(d)$. 


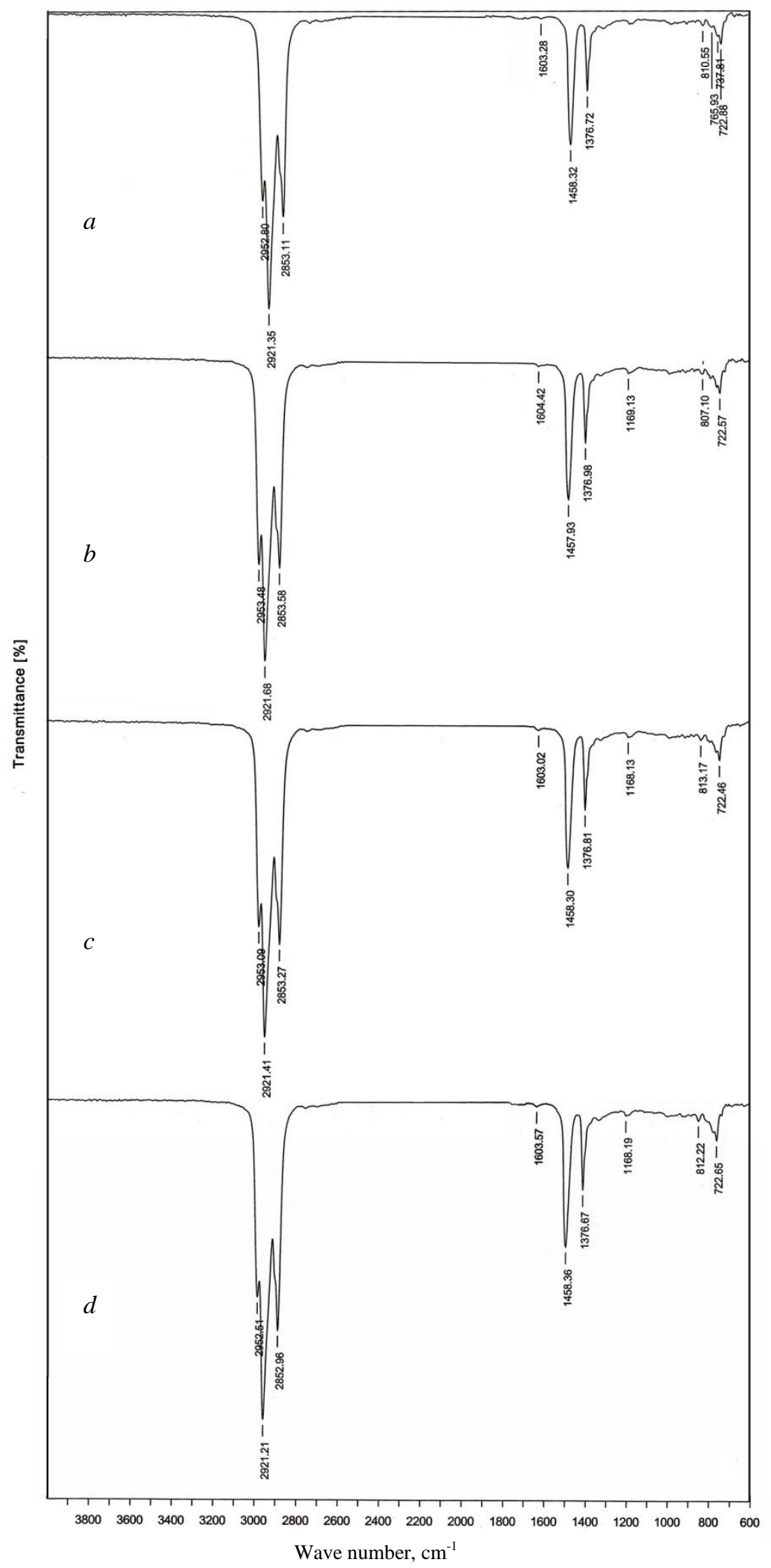

Fig. 2. IR spectra of the raffinates obtained on the basis of corresponding diesel distillates: on the basis of initial DD $(a)$, on the basis of DD of the I fr. $(b)$, on the basis of the II fr. $(c)$, on the basis of DD of the III fr. (d). 


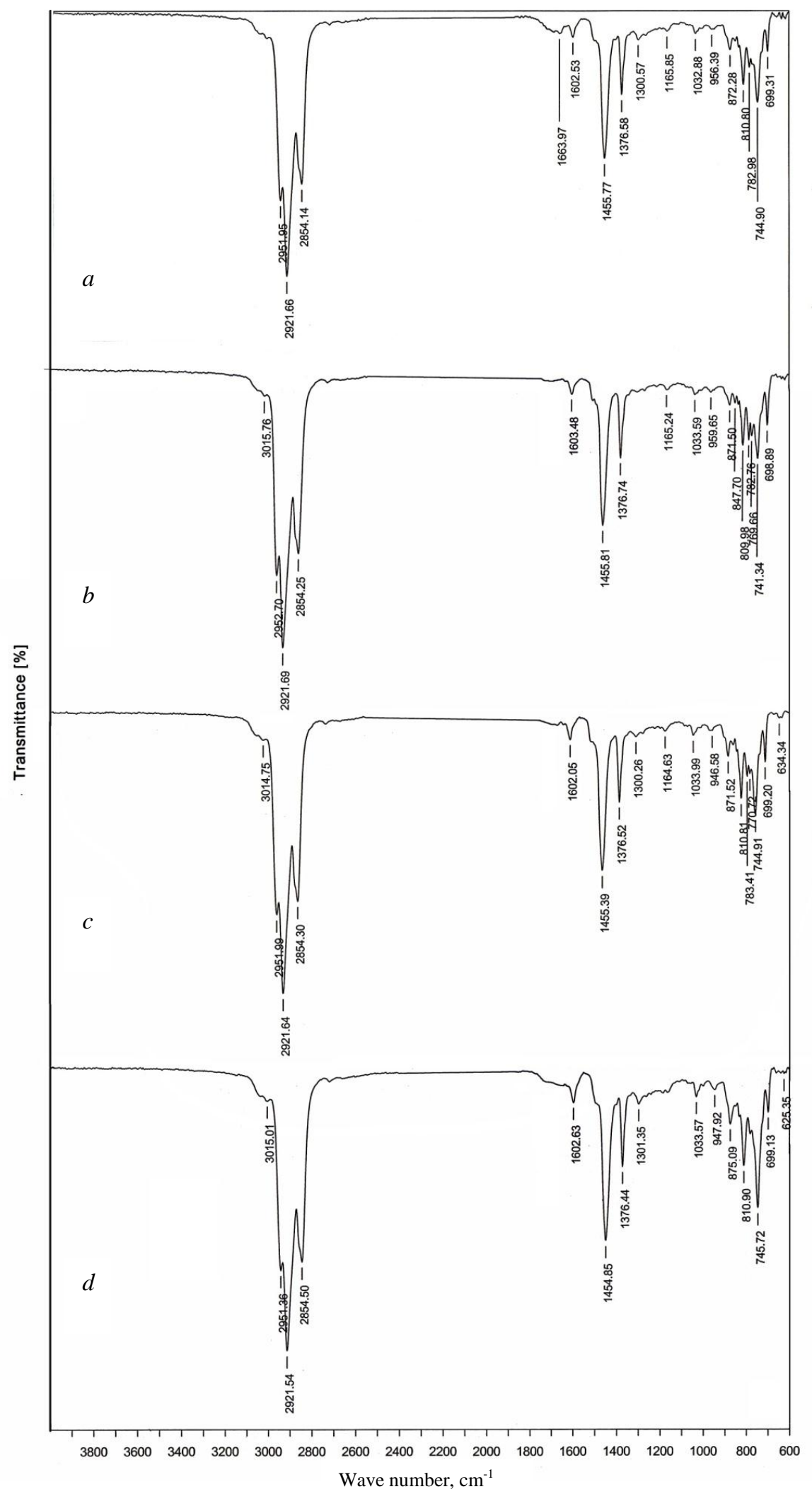

Fig. 3. IR spectra of the extracts, obtained on the basis of corresponding diesel distillates: on the basis of initial DD $(a)$, on the basis of DD of the I fr. $(b)$, on the basis of the II fr. $(c)$, on the basis of the III fr. $(d)$. 
Table 3. Optical densities of diesel distillates and corresponding raffinates and extracts obtained on their basis

\begin{tabular}{|l|c|c|c|c|c|}
\hline \multicolumn{1}{|c|}{ Sample name } & $\mathrm{D}_{1376}$ & $\mathrm{D}_{1458}$ & $\mathrm{D}_{970}$ & $\mathrm{D}_{1033}$ & $\mathrm{D}_{1604}$ \\
\hline Initial diesel distillate & 0.056 & 0.097 & - & - & 0.007 \\
\hline Raffinate of initial diesel distillate & 0.054 & 0.095 & - & - & 0.001 \\
\hline Extract of initial diesel distillate & 0.054 & 0.100 & 0.010 & 0.013 & 0.015 \\
\hline Diesel distillate of fr.191-250 ${ }^{\circ} \mathrm{C}$ & 0.058 & 0.103 & - & - & 0.006 \\
\hline Raffinate of diesel distillate of fr. $191-250^{\circ} \mathrm{C}$ & 0.059 & 0.102 & - & - & 0.001 \\
\hline Extract of diesel distillate of fr.191-250 $\mathrm{C}$ & 0.055 & 0.104 & 0.003 & 0.006 & 0.013 \\
\hline Diesel distillate of fr. $250-300^{\circ} \mathrm{C}$ & 0.060 & 0.105 & - & - & 0.006 \\
\hline Raffinate of diesel distillate of fr. $250-300^{\circ} \mathrm{C}$ & 0.060 & 0.104 & - & - & 0.002 \\
\hline Extract of diesel distillate of fr. $250-300^{\circ} \mathrm{C}$ & 0.060 & 0.106 & 0.004 & 0.008 & 0.018 \\
\hline Diesel distillate of fr. $300-345^{\circ} \mathrm{C}$ & 0.063 & 0.109 & - & - & 0.007 \\
\hline Raffinate of diesel distillate of fr. $300-345^{\circ} \mathrm{C}$ & 0.061 & 0.105 & - & - & 0.002 \\
\hline Extract of diesel distillate of fr. $300-345^{\circ} \mathrm{C}$ & 0.064 & 0.109 & 0.005 & 0.010 & 0.022 \\
\hline
\end{tabular}

\section{Conclusions}

Thus, the article presents the possibility of using ionic-liquid composition on the basis of $\mathrm{N}$-methylpyrrolidone and acetic acid as an extractant in selective purification of diesel distillate instead of organic solvents, and it's considered advanced development of ecologically safe technologies for the production of diesel fuel.

\section{References}

1. Energy Strategy of Russia for the period up to 2030 year [electronic resource]: http://pravo.gov.ru

2. Pat. №2362797 RF. The method for obtaining dearomatized diesel fuel with ultra-low sulphur content / Loginova A.N., Kitova M.V., Fadeyev V.V., Lysenko S.V., Ivanov A.V. 200909.

3. Krasnogorskaya N.N. Extraction of middle petroleum fractions / Krasnogorskaya N.N., Gabdikeyeva A.R., Grushevenko A.E., Khlestkin R.N. M.: Khimiya. 1989. 72 p.

4. Garifullin T.M. Reduction of sulphur content in diesel fuel is one of the priority tasks of oil refineries / Garifullin T.M., Dyachenko D.I., Zolnikov V.V. Ufa. Neftegazopererabotka. 2009. P. 141-142.

5. Appazov A.Y. Production of high-quality diesel fuels by liquid extraction method / Appazov A.Y. Pykhalova N.V., Balamedova U.A. // Proceedings of high schools. Chemistry and Chemical Technology. 2012. V. 55. Iss. 2. P. 71-73.

6. Khalikov D.E., Obukhova S.A., Vezirov R.R. Optimization of extraction process of diesel fuel by the method of numerical experimentation //Refining and petrochemistry. 2000. No 1. P. 46-48.

7. Khalikov D.E., Obukhova S.A., Vezirov P.P. Regularities of extraction of various classes of aromatic hydrocarbons during the extraction of the diesel fraction of $270-340^{\circ} \mathrm{C} / /$ Refining and petrochemistry - with domestic technology in the XXI century: Materials of the B2 section of the Congress of oil and gas producers of Russia. Ufa: Publ. House: IPNCP of the Academy of Sciences of RB, 2000. P. 122-124.

8. Khalikov D.E., Obukhova S.A., Vezirov R.R. and et al. Modeling of five-step extraction of arenes from straight-run fraction $270-360^{\circ} \mathrm{C}$ with watered 1,4-dioxane // Integration of science and higher education in the field of organic and bioorganic chemistry and mechanics of multiphase systems: Materials 2 of All-Russian scientific INTERNETconference. Ufa, December 15-30 2003. Ufa: Reactive. 2003. P. 98.

9. Beiko O.A., Golovko A.K., Gorbunova L.V. Chemical composition of West Siberian oils. Novosibirsk: Nauka, Sib. Branch. 1988. 288 p.

10. A room temperature process for removing sulphur from fuels // Chem. Eng. (USA). 2002. V. 109. No 10. P. 17.

11. Ibrahimova M.J., Azizov A.H., Azmamedov H.G., Eyvazov E.Z., Aliyeva S.G., Naghiyev V.A. Ionicliquid purification of diesel fuel // Processes petrochem. oil refining. 2006. № 4(27). P. 29-33.

12. Ibrahimova M.J., Azizov A.H., Sultanov S.A., Naghiyev V.A., Aliyeva S.G., Mamedov R.B. Selective purification of diesel fuel by ionic-liquid content on the basis of formic acid and morpholine // World of Oil Products. 2009. № 3. P. 20-22.

13. Ibrahimova M.D., Aliyeva S.G., Seidova S.A., Huseynov H.J., Abbasov V.M., Naghiyev V.A. Improvement of quality of the hydropurified diesel fuel by ion-liquid extraction // Int. J. Sci. Eng. Appl. Science (IJSEAS). V. 4. Iss. 5. May. 2018. P. 91-94. 


\section{DIZEL DISTILLATI VO ONUN DAR FRAKSIYYLARININ EKSTRAKSIYYA ÜSULU İLO SEÇICI TəMIZLLNMəSI}

\section{M.C.İbrahimova, S.A.Seyidova, S.Q.Đliyeva, H.C.Hüseynov, V.Ө.Nağıyev, Ә.B.Xəlilov, S.F.Ohmədbəyova, S.Ş.Hüseynova}

Məqalədə dizel distillatı və onun əsasında alınmlış fraksiyaların N-metilpirrolidon və sirkə turşusu əsasında sintez edilmiş ion maye tərkibdən seçici həlledici kimi istifadə etməklə alınmış rafinat və ekstraktın karbohidrogen qrup tərkibinin İQ-spektral analizi üsulu ilə tədqiqindən alınmış nəticələr verilmişdir. Müqayisəli olaraq qeyd edilmiş tərkiblərin N-metilpirrolidonla seçici təmizlənməsi prosesi həyata keçirilmiş ion-maye tərkibdən ekstragent kimi istifadən məqsədyönlü və perspektiv olduğu müəyyən edilmişdir.

Açar sözlori: ion mayesi, ekstraksiya, ekstragent, distillat, dizel yanacă̆l, seçici halledici, rafinat, ekstrakt.

\section{ЭКСТРАКЦИОННОЕ ОБЛАГОРАЖИВАНИЕ ДИЗЕЛЬНОГО ДИСТИЛЛЯТА И ЕГО УЗКИХ ФРАКЦИЙ}

\section{М.Д.Ибрагимова, С.А.Сеидова, С.Г.Алиева, Г.Д.Гусейнов, В.А.Нагиев, А.Б.Халилов, С.Ф.Ахмедбекова, С.Ш.Гусейнова}

Приведены результаты исследований исходных дизельных дистиллятов, а также рафинатов и экстрактов, полученных экстракционной очисткой указанных дистиллятов с использованием в качестве избирательного растворителя ионной жидкости на основе N-метилпирролидона и уксусной кислоты. ИК-спектральным анализом установлены углеводородные составы рафината и экстракта, полученных селективной очисткой дизельного дистиллята и его узких фракций. Показаны преимущество и перспективность применения ионной жидкости по сравнению с N-метилпирролидоном в процессах селективной очистки дизельного дистиллята.

Ключевые слова: ионная жидкость, экстракция, экстрагент, дистиллят, дизельное топливо, избирательный растворитель, рафинат, экстракт. 